International Reserves and the Composition of Equity Capital Inflows Xingwang Qian and Andreas Steiner

\author{
Working Paper 90 \\ January 2012
}

INSTITUTE OF EMPIRICAL ECONOMIC RESEARCH

University of Osnabrueck

Rolandstrasse 8

49069 Osnabrück

Germany 


\title{
International Reserves and the Composition of Equity Capital Inflows
}

\author{
Xingwang Qian and Andreas Steiner
}

January 2012

\begin{abstract}
We study the effect of central banks' international reserve hoardings on the composition of equity capital inflows, namely the ratio of portfolio equity investment (PEI) to foreign direct investment (FDI). Foreign investors' decisions regarding the location and the type of equity capital investment might be influenced by a country's level of international reserves. In a simple theoretical model, we show that higher reserves, thanks to their ability to lower exchange rate risk, reduce the risk premium of portfolio equity inflows. Hence, higher reserves are expected to increase the inflow of portfolio equity investment relative to FDI. We test this hypothesis for a sample of emerging markets during the period 1980-2007 using static and dynamic panel data methods. The results suggest that higher levels of reserves are associated with a larger ratio of PEI inflows relative to FDI. This result points to a collateral benefit of reserves that has been neglected so far: Reserves contribute to deeper domestic financial markets and facilitate domestic firms’ access to foreign financing.
\end{abstract}

Keywords: International Reserves, Capital Inflows, Equity Capital JEL Classification Numbers: F3, F4

Corresponding Addresses:

Xingwang Qian, Economics and Finance Department, SUNY Buffalo State, Buffalo, NY 14222, USA, Email: qianx@buffalostate.edu

Andreas Steiner, Institute of Empirical Economic Research, University of Osnabrück, 49069 Osnabrück, Germany, Email: asteiner@uni-osnabrueck.de 


\section{Introduction}

The global financial crisis of 2008-10 has highlighted the flip side of financial globalization: Global interdependencies facilitated the spread of the crisis around the globe. This has renewed the interest in the role played by different types of capital flows during periods of financial distress ${ }^{1}$. Moreover, the discussion of how policies can influence the composition of capital inflows and hence affect economic growth has been intensified. ${ }^{2}$

In emerging markets international reserves have been employed as an important monetary policy tool to signal domestic financial health, to self-insure against financial crises, and to demonstrate a country's ability to stabilize its exchange rate. International reserves may affect the behavior of foreign investors through two channels: First, the accumulation of reserves creates expectations that the central bank stabilizes the exchange rate in the future. As a consequence, market participants discount exchange rate risk. Second, reserves reduce the perceived risk of the investment because they create bailout expectations. In a nutshell, reserve hoardings are perceived as an implicit insurance of investors and may enhance capital inflows.

This implicit insurance value of reserves might affect the decision process of borrowers and creditors engaged in cross-border capital flows, for instance, the choice between domestic and foreign borrowing, the currency denomination of external debt, the form of financing (FDI, PEI or debt) and the time-horizon of the debt relationship. ${ }^{3}$

This paper focuses on the form of external financing, particularly reserves' impact on the composition of foreign equity capital inflows, namely portfolio equity investment (PEI)

\footnotetext{
${ }^{1}$ Appendix A provides a brief review of the literature.

${ }^{2}$ See, among others, Milesi-Ferretti and Tille (2011); Ostry et al. (2010); Reinhart and Rogoff (2011) and Tong and Wei (2011).

${ }^{3}$ See Hale (2007) and Tirole (2003) for the form of financing. The currency denomination of external debt is usually examined in the context of the exchange rate regime, whose credibility, in turn, depends on the level of reserves (see Burnside et al., 2001; Martínez and Werner, 2002).
} 
and foreign direct investment (FDI) ${ }^{4}$. In particular, we examine whether the level of reserves affects the ratio of PEI to FDI.

FDI and PEI are the two most important components of the global capital market, particularly in emerging markets. Together they accounted for about $64 \%$ of capital flows to emerging markets in 2010 (McKinsey Global Institute, 2011). They provide many benefits to both investors and the recipient country: They enable investors to diversify their portfolio and reduce investment risks. They also propel the integration of the global capital market, which arguably contributes to the spread of best practices of corporate governance, legal practice, and accounting standards, and has a disciplinary effect, which limits a government's ability, especially in emerging markets, to pursue bad policies.

FDI and PEI, individually, bring pros and cons to both investors and the host country. On the one hand, FDI contributes to the transfer of advanced technologies, provides management know-how, and improves market accessibility. On the other, due to increased competition, it could crowd out the local industry. PEI provides market liquidity for economic growth, but it may come to a sudden stop during financial stress due to its volatile nature. From the point of view of foreign equity investors, FDI helps to explore local markets, hence reap high returns; but it is hard to liquidize (fire-sale) during episodes of economic downturn. Thus investors may suffer from substantial losses. In contrast, PEI is easy to liquidize but has to pay an extra risk premium due to asymmetric information (Goldstein and Razin, 2006).

These different effects have raised many policy related issues. How to harness those pros and cons to benefit the most out of both FDI and PEI? What determines the composition

\footnotetext{
${ }^{4}$ By convention, an investment is considered as FDI when the equity share exceeds $10 \%$ of the voting stock. FDI can be in the form of a new production facility (greenfield investment) or a major shareholding in an existing firm (M\&A activities). PEI refers to foreigners directly purchasing stocks in the local stock market with the total share being below $10 \%$.
} 
of FDI and PEI? Why do some countries rely more on FDI, while others intend to have more PEI? If desired, what policies can alter the composition?

Despite the increasing interest in the composition of foreign equity inflows (Goldstein et al., 2010; Kirabaeva and Razin, 2010; Lane and Milesi-Ferretti, 2000), very little work has been done on how international reserves affect the equity inflow composition. This paper is the first to evaluate this relationship both theoretically and empirically and to draw some policy implications. We show formally that higher reserves reduce the risk premium of PEI and hence make PEI more attractive relative to FDI. We then confront our hypothesis with the data: We conduct a panel data analysis for a set of emerging markets over the period 1980-2007.

As an illustration of the data, Figure 1 shows the bivariate relationship between reserves and the composition of equity investment in the sample-averaged data from 1980 to 2007 and two individual sample countries, namely Brazil and Malaysia. It provides first simple evidence that both variables are positively associated.

To anticipate the results, we find that a high level of international reserve holdings in an emerging market is associated with a high proportion of PEI relative to FDI. This result is robust across different model specifications including alternate sets of control variables and across estimation procedures, namely static and dynamic panel data regressions.

This paper bridges the gap between two major strands of the literature, which have not been considered together so far: First, it relates to the literature that evaluates the costs and benefits of the accumulation of international reserves. Second, it links to papers that examine the determinants and consequences of the composition of capital flows.

The paper is organized as follows: In section 2, we describe the possible theoretical mechanism through which international reserves affect the composition of foreign equity investment, PEI versus FDI. Section 3 empirically studies our theoretical hypothesis. We 
briefly describe the implications of the composition of foreign equity investment for a recipient emerging market in Section 4. Section 5 concludes.

\section{Theoretical considerations}

What are the theoretical channels through which international reserves might affect the composition of capital flows? This section presents a simple theoretical model that shows the impact of the level of reserves on the composition of equity inflows, namely the ratio of PEI to FDI flows.

We build the model from the perspective of a risk-averse investor who diversifies her portfolio internationally. The return of both FDI and PEI depends on common countryspecific factors and risks ${ }^{5}$ : First, the return of the equity investment depends on the stance of the business cycle (see Fama, 1981). Second, macroeconomic policies like trade policy, labour market regulations and exchange rate policy affect the competitiveness of the firm in international markets and its return. Third, political instability, the risk of expropriation and enforcement problems may reduce the return of both FDI and PEI. Fourth, devaluations increase the competitiveness of local production and may enhance returns of both FDI and PEI.

Compared to home equity investments and FDI, PEI is subject to an important additional risk factor: exchange rate risk. The return of FDI is primarily related to economic fundamentals of the host country, while the return of PEI tends to be influenced by exchange rate fluctuation in that the value of PEI shares, expressed in foreign currency, decreases with the depreciation of the home currency while the value of real assets is unaffected.

Malliaropulos (1998) shows in a theoretical model that a real depreciation decreases the price of domestic stocks relative to foreign ones. Lane and Milesi-Ferretti (2008) explain

\footnotetext{
${ }^{5}$ We focus on macroeconomic risks in this paper. There exist firm-specific risks that affect the return of an individual investment. However, we do not consider this in our analysis as our macroeconomic model is based on a representative firm.
} 
that the relatively small cross-border holdings of portfolio equity assets and liabilities in emerging markets compared to advanced economies are due to the presence of high currency risk in emerging markets. The findings with respect to the direction of causality between exchange rate returns and stock market returns are ambiguous. ${ }^{6}$ However, it is a welldocumented fact that the pair is positively related.

During episodes of currency crisis, the exchange rate devaluation is usually associated with a drastic outflow of PEI and a simultaneous inflow of FDI. For instance, Krugman (2000) points out that the Asian financial crisis was accompanied by a wave of inward direct investment. This may suggest that currency crises mainly affect the behavior of PEI, while FDI is resilient to an exchange rate devaluation.

International reserves can be used to signal financial health of an emerging market, to stabilize the exchange rate, and to smooth necessary adjustments. It therefore reduces the perceived probability of incurring an output-loss currency crisis (Aizenman and Marion, 2004). Further, reserves can mitigate the extent and severity of a crisis (Obstfeld et al., 2009). In addition, reserves have been found to alleviate the impact of terms-of-trade shocks on the real exchange rate (Aizenman and Riera-Crichton, 2008). Hence, reserves reduce the passthrough from terms-of-trade shocks on stock market returns.

Since FDI is resilient to currency crises and currency crises primarily affect the behavior of PEI, we focus on PEI and model the return on PEI as an interest-rate-like yield in an environment of possible currency crises. In contrast to bonds with a fixed interest rate, the return of equities is an expected value and depends on the share price and future dividend payments. This modeling strategy is consistent with alternative methods to calculate stock prices and returns: In the corporate finance based method, the share price equals the discounted stream (present value) of expected dividend payments. Alternatively, one may

\footnotetext{
${ }^{6}$ Granger et al. (2000) find that causality between stock markets and exchange rates runs in both directions.
} 
link the share price directly to the value of the firm, which depends on investment, production function and productivity shocks (Kirabaeva and Razin, 2010).

Consider the following no arbitrage condition according to which the expected PEI rate of return measured in the investor's currency equals the risk-free world interest rate $r$ :

$$
\left(1+r^{P E I}\right) \cdot \frac{E_{t+1}}{E_{t}}=(1+r)
$$

where $\left(r^{P E I}\right)$ is the expected PEI rate of return expressed in the currency of the equity investment and $E$ is the nominal exchange rate such that $E_{t+1} / E_{t}$ accounts for changes in the exchange rate. $t$ denotes the time index.

The probability of a currency-crisis induced devaluation is given by $p$. Assume that with probability $(1-p)$ the nominal exchange rate is constant. ${ }^{7}$ Hence, equation (1) can be expressed as:

$$
(1-p) \cdot\left(1+r^{P E I}\right)+p q \cdot\left(1+r^{P E I}\right)=(1+r)
$$

where $q=\frac{E_{t+1}}{E_{t}}$ can be considered as the recovery ratio with $q<1$ when the local currency devaluates in a currency crisis.

Equation (2) can be solved for the risk premium (RP), which is defined as the difference between the implicit interest rate on PEI and the risk-free world interest rate $\left(r^{P E I}-r\right)$

$$
R P=\left(1+r^{P E I}\right) \cdot(p-p q)
$$

Theoretical models and empirical evidence suggest that both the probability of devaluation (Aizenman and Marion, 2004; Frankel and Saravelos, 2010; Li and Rajan, 2009) and its extent in case of a crisis (De Gregorio and Lee, 2004; Obstfeld et al., 2009) depend

\footnotetext{
${ }^{7}$ For model simplicity, we assume 1-p to be the probability of a constant exchange rate. The model can be easily extend to the scenario of appreciation, in which $(1-p) \cdot \theta \cdot\left(1+r^{P E I}\right)+p q \cdot\left(1+r^{P E I}\right)=(1+r)$, where $\theta$ is a constant and $\theta>1$. The model result is the same as the one presented in the text.
} 
negatively on the level of international reserves. In the light of these findings we assume that $p$ decreases in the level of reserves and $q$ is positively associated with reserves.

The partial derivative of the risk premium with respect to international reserves is given by

$$
\frac{\partial R P}{\partial I R}=\left(1+r_{P E I}\right) \cdot\left(p_{I R}(1-q)-p q_{I R}\right)<0
$$

where the index $I R$ indicates the first derivative with respect to international reserves. By assumption $p_{I R}<0$ (higher reserve holdings lower the probability of a currency crisis) and $q_{I R}>0$ (higher reserves holdings increase the recovery ratio).

The theoretical result suggests that higher levels of reserve reduce the risk premium of PEI in that higher reserves reduce both the probability and the extent of currency devaluation. Due to the resilience of FDI to currency crises, FDI is less sensitive to exchange rate risk and the reduction in the risk premium mainly applies to PEI. Consequently, PEI is a more attractive form of investment for foreign investors in an emerging market if the level of international reserves is high.

Thus, we postulate that higher international reserves increase the ratio of PEI to FDI. Our hypothesis does not necessarily imply that PEI substitutes for FDI. It rather states that international reserves help countries to attract a higher ratio of PEI to FDI without making any assumptions regarding the absolute levels of both PEI and FDI.

There is a caveat in our theory discussion, in which we implicitly assume that the return of FDI is not affected by a currency crisis due to its resilience to the crisis and leave the FDI out of our model. However, there are many cases that a foreign investor may liquidate (or fire-sale) her FDI in a currency crisis due to depressed future output expectations. In such a fire-sale, the price is usually deeply discounted compared to the fairmarket price in tranquil times (Acharya et al., 2011; Aguiar and Gopinath, 2005). 
The exchange rate devaluation, however, primarily affects PEI for several reasons. For instance, the selling price of a PEI is denominated in domestic currency, while the FDIseller may price the investment in foreign currencies. Moreover, FDI prices are more likely to take the long-run prospects of the firm into account, whereas PEI share prices might be distorted by temporary uncertainties, negative demand effects due to portfolio allocation adjustment and panics. Finally, as described before, while the return of both PEI and FDI is negatively affected by crisis-induced lower output, the pure exchange rate risk of a devalued currency mainly applies to PEI because of its denomination in the devalued currency.

Thus, we use the risk premium of FDI as the benchmark. To simplify the model, we assume the benchmark return as the risk-free world return.

\section{Empirical analysis}

In this section, we empirically test the hypothesis derived in the previous section. Our sample includes 23 emerging markets ${ }^{8}$ and ranges from 1980 to 2007 with the last year determined by data availability. We use two econometric approaches to investigate how international reserves affect the composition of equity capital inflows to emerging markets - static panel data regression and dynamic panel data regression.

\subsection{The Static Panel Data Approach}

Since we have cross-country time series data, we first consider the commonly used static fixed effects panel data regression ${ }^{9}$. We estimate the following equation,

$$
\frac{P E I_{i, t}}{F D I_{i, t}}=\alpha \cdot X_{i, t}+\beta \cdot Y_{i, t}+\gamma \cdot Z_{i, t}+\varepsilon_{i, t}
$$

\footnotetext{
${ }^{8}$ The country sample size is dictated by data availability. The included emerging markets are Brazil, Chile, China, Colombia, Czech Republic, Egypt, India, Hungary, Indonesia, Israel, Korea, Malaysia, Mexico, Morocco, Peru, Philippines, Poland, Romania, Russia, Saudi Arabia, South Africa and Thailand.

${ }^{9}$ The Hausman test rejects a random effects regression.
} 
where, the dependent variable, $P E I_{i, t} / F D I_{i, t}$, is the ratio of a country's stock of portfolio equity inflows (PEI) to the stock of FDI inflows. $i$ and $t$ are the country and year indices, respectively. Data of PEI and FDI are both taken from the EWN II data set of Lane and Milesi-Ferretti (2007).

For the independent variables, we follow the pull and push factors approach (Calvo et al, 1993; Chuhan et al., 1996; Montiel and Reinhart, 1999), which distinguishes the pull factors (e.g. domestic factors in the recipient country) and push factors (e.g. external or world factors). Thus, in the regression model we include pull and push factors for both FDI and PEI that have been identified as important determinants in the literature.

$X_{i, t}$ is a vector, which contains factors affecting PEI inflows to an emerging market. Those factors include stock market capitalization, institutional quality (proxied by the index of corruption and law and order from ICRG; lower institutional quality means lower efficiency of the equity transaction technology and more informational frictions), international reserves (the ratio of international reserves to GDP), and a push factor - the world factor (three-month US Treasury bill rate). ${ }^{10}$

$Y_{i, t}$ is a vector of FDI determinants including the market size of an emerging market (proxied by GDP), the endowment with natural resources (the sum of oil and mineral output), trade openness, institutional quality (same definition as for PEI), and the world factor (the 10year US Treasury bond yield). Finally, $Z_{i, t}$ contains common factors that affect both PEI and FDI, such as the GDP growth rate. A time trending variable is also included in $Z_{i, t}$ to control for a possible trend in the time series. A detailed definition of each variable can be found in Appendix B.

We use contemporaneous variables as regressors. This implies that we have to address carefully the problem of possible endogeneity, e.g. reverse causality. A typical way to deal

${ }^{10}$ See for example, Chuhan et al. (1998), Portes and Rey (2005), and Fernandez-Arias (1996). 
with such a problem is to transform the possible endogenous variables into predetermined variables, e.g. lagged by one period. ${ }^{11}$ However, we consider this method improper in the context of this paper, in which we use annual data to study the behavior of short-term capital flows. In the modern financial world, capital flows usually respond to changes of economic indicators in a very short period of time. A few episodes of drastic capital reversals during financial crises in emerging markets, e.g. Mexico and East Asia, are the best examples, where billions of cross-border capitals were withdrawn in a few months. In other words, capital flows probably would not wait for one year to react to the outdated information revealed a year ago.

Thus we suspect that both FDI and PEI are driven by decisions that are based on information revealed in the same year and we prefer to keep contemporaneous terms in the regression. The same practice is adopted by, for example, Goldstein et al. (2008) and Faria et al. (2007).

Since our dependent variable is constructed as the ratio of PEI to FDI, we expect factors that positively affect FDI to have a negative effect on the dependent variable; i.e. trade openness, which is meant to positively affect FDI (a high level of trade openness is associated with high FDI inflows.), is expected to negatively affect the ratio of PEI to FDI. The positive-effect factors of PEI, in turn, are expected to have a positive impact on the ratio of PEI to FDI.

We performed a fixed effects panel regression. However, there is AR(1) serial correlation in the error term of regressions, which biases the results. We thus use the Feasible GLS technique to adjust the AR(1) series correlation. The results are reported in Column A of Table 1.

\footnotetext{
${ }^{11}$ An alternative method is using instrumental variables.
} 
We find that international reserves scaled by GDP indeed enter with a strongly significant and positive coefficient, thus confirming our hypothesis that higher international reserves attract more PEI relative to FDI. A $1 \%$ increase in reserves is suggested to be associated with an increase of $0.77 \%$ in the ratio of PEI to FDI.

Other factors related to PEI, namely stock market capitalization and institutional quality, are also significant - a larger domestic stock market and better domestic institutional quality increase PEI relative to FDI. These findings are in line with other papers, e.g. Wei and Wu (2002). Strictly speaking, institutional quality affects both PEI and FDI. For PEI, better institutional quality represents less informational frictions and better transaction technology in the domestic stock market. Portes and Rey (2005) find that institutional quality is among the most important determinants of portfolio flows. On the FDI side, an environment characterized by better institutional quality, theoretically, attracts more FDI. However, this intuition does not garner consensus in empirical studies. For instance, Wheeler and Mody (1992) find no evidence for a significant relation between FDI and institutional quality. Further, Fernandez-Arias and Hausman (2001) indicate that a country with weaker institutions tends to attract less capital but more of it in the form of FDI. Our result is congruous with Fernandez-Arias and Hausman (2001). Other PEI factors, the world short term interest rate and real GDP growth are not significant.

Regarding FDI factors, only trade openness shows up significantly - it reduces the ratio of PEI to FDI. Trade openness is positively associated with FDI, which is the denominator of our dependent variable. Thus, a higher degree of trade openness reduces the ratio of PEI to FDI. The remaining FDI factors, GDP, the endowment with natural resources, the world long-term interest rate, and real GDP growth are insignificant.

There is a plethora of discussions about the experience of sudden outflows of shortterm capital during crises in emerging markets. The literature argues that a crisis with self- 
fulfilling mechanism can lead to a large-scale capital reversal even if there is no shock to economic fundamentals (Caballero and Krishnamurthy, 2001). FDI, in turn, seems to be consistent in both tranquil and crisis periods; in fact, a financial crisis may be associated with an outflow of foreign PEI and a simultaneous inflow of FDI (Krugman, 2000). Hence, we anticipate that financial crises affect PEI and FDI differently.

We thus add a few crisis-related variables to the regression to examine our anticipation and the robustness of our model results. We include three crisis variables - all of them are dummy variables. The first one, called Crisis, is calculated according to the method of Kaminsky and Reinhart (1999) and measures whether a crisis happened in a specific country. In addition, a large-scale regional financial crisis usually imposes substantial contagious effects on other countries. We thus include two notorious financial crises, Mexico 1994 and East Asia 1997, to address possible contagion.

Column B reports the results of the regression including three crises variables. All three crises variables enter negatively. Although the Crisis variable is not significant, both the Mexican crisis 1994 and the East Asian crisis 1997 significantly reduce the ratio of PEI to FDI, which is in line with the crisis literature. Our previous results are quite robust to adding the crisis variables. They do not change, except for the world long-term interest rate, which, interestingly, becomes significantly negative. Intuitively, higher world long-term interest rates divert long-term investment in emerging markets, e.g. FDI, to the rest of the world (mostly industrial countries). If this is true, we should expect a positive coefficient estimate. One plausible explanation for the negative impact of the world long-term interest rate is that higher interest rates in industrial countries reduce investors' risk appetite and lead to a general reduction of investment in emerging markets. PEI is more easily and rapidly liquidated and flows back. 
In principle, capital account policies, e.g. capital controls, in the recipient country have a direct effect on both the volume (Malaysia's capital controls right after the 1997 financial crisis) and the composition of capital inflows (Chilean type of capital controls). Montiel and Reinhart (1999) present evidence that capital controls influence the composition of capital flows, but not their volume. Hence, when studying the composition of capital flows, ignoring the effect of capital controls would be a mistake.

Thus, we add a capital control variable to the regression. Ideally, we need information on capital controls that distinguishes between controls on short-term and long-term capital inflows. ${ }^{12}$ However, a large variety of capital controls has been created and implemented, and the empirical measurement of capital controls appears to be a challenge. ${ }^{13}$ We rely on a commonly used measure of capital restrictions - the Chinn-Ito index - as the proxy to control for the effect of capital controls.

The results are presented in Column $\mathrm{C}$ of Table 1. They suggest that capital controls do not have a significant effect on the composition of equity flows, although the estimated coefficient is negative.

To sum up, for a sample of 23 emerging markets we are able to confirm empirically our hypothesis derived from the theory in Section 2 . The results are robust to the inclusion of additional variables, e.g. financial crises and capital controls.

\subsection{The Dynamic Panel Data Approach}

In this section, we use a dynamic panel data regression to further study how international reserves affect the composition of foreign equity investment.

\footnotetext{
12 There are many varieties of capital controls, some target short-term capital inflows, some aim at the outflow, and some are imposed on long term capital flows (See International Monetary Fund, Annual Report on Exchange Arrangements and Exchange Restrictions (AREAER)).

${ }^{13}$ See for example, Magud et al. (2011) for a discussion of issues related to research on capital controls.
} 
In essence, the static panel data model specification in Section 3.1 is based on a partial equilibrium model. That is, it examines the determinants of the ratio of PEI to FDI in equilibrium. However, the capital flow structure may deviate from its “equilibrium” value if the adjustment process is gradual (Faria et al., 2007).

To accommodate such a gradual process, we follow the partial stock adjustment model of Chow (1967),

$$
y_{i, t}=(1-\rho) \cdot y_{i, t-1}+\rho \cdot y_{i, t}^{*}
$$

where $y_{i, t}$ is the actual capital position and $y_{i, t}^{*}$ is the "equilibrium" capital position, both determined in period $t$; $(1-\rho)$ indicates the speed of adjustment.

We can apply the above reasoning to our model by specifying a dynamic panel data generating process as the following,

$$
\frac{P E I_{i, t}}{F D I_{i, t}}=\theta \cdot \frac{P E I_{i, t-1}}{F D I_{i, t-1}}+\alpha \cdot X_{i, t}+\beta \cdot Y_{i, t}+\gamma \cdot Z_{i, t}+\varepsilon_{i, t}
$$

where we basically augment equation (3) with a lagged dependent variable to form a dynamic panel data regression.

When a lagged dependent variable is included in the estimation, the panel data OLS regression is biased and inconsistent (Anderson and Hsiao, 1981). A commonly used alternative approach, provided by Arellano and Bond (1991), Arellano and Bover (1995), and Blundell and Bond (1998) is the System Generalized Method of Moments (GMM) estimator, which provides unbiased and consistent estimates in a dynamic panel data environment.

Despite the possible bias, we present the results of a dynamic fixed effects panel regression in Table 2. Although we do not try to interpret the results, they provide some useful information because they can be compared to the improved results of the SystemGMM estimation. 
The System GMM is designed to deal with issues that arise in a linear functional relation, for example, 1) the dependent variable is dynamic and depends on its own past realization; 2) heteroskedasticity and autocorrelation; and 3) independent variables that are not strictly exogenous - either correlated with the error term or subject to reverse causality. The last point is particularly appealing for our empirical exercise as we have to address the problem of possible endogeneity due to our use of contemporaneous explanatory variables.

Although System GMM provides many advantages, it is complicated to implement and can easily generate invalid estimates. To cope with the complexity, the key is to obtain proper instruments, to guarantee the overall validity of the moment conditions, and to control for serial correlation in the error term of the equation in levels. We employ the Hansen Test (Hansen, 1982) to check for the overall validity of the selected moment conditions and use the Arellano and Bond (1991) Test to check for possible serial correlation in the level equation.

In addition, there is a specific issue associated with our exercise when using the System GMM. That is, the long time dimension of our data set (1980 -2007) may cause too many instruments, which potentially makes the two-step System GMM almost useless for inference (Arellano and Bond, 1991). To deal with this issue we use one-step System-GMM instead, which is theoretically less efficient than the two-step counterpart. However, according to Windmeijer's (2005) test, the difference between both is only marginal.

Columns A, B, and C of Table 3 present the results of estimating equation (4). The lagged dependent variable estimate is highly significant across all three regressions. The results thus confirm that the composition of PEI and FDI adjusts gradually. The speed of adjustment to equilibrium is about $15 \%$ per year.

Our main hypothesis is confirmed once again in the dynamic model specification. The value of the coefficient of international reserves has doubled compared to the results of Table 
1. It suggests that international reserves have a greater impact on the ratio of PEI to FDI once the dynamic adjustment process is controlled for.

The other estimates are similar to those of Table 1. Two PEI pull factors, stock market capitalization and institutional quality, are significant. The same holds for the pull factor of FDI, trade openness. Interestingly, both the Mexican financial crisis and the East Asian financial crisis become insignificant. The country-specific crisis dummy, however, turns out to be significant. In line with conventional wisdom, a financial crisis in an emerging market decreases the ratio of PEI to FDI by approximately 15\%. We do not find a significant effect of capital controls.

\section{Implications of the composition of foreign equity capital inflows}

Understanding the pros and cons of PEI and FDI and the effect that international reserves impose on the composition of equity capital inflows is pivotal for policy makers who aim at making proper adjustments to international reserve holdings in order to extract most benefits out of both PEI and FDI.

In contrast to international debt flows, whose fixed interest rate is independent of the return earned in the investment project, FDI and PEI are forms of risk sharing between domestic borrowers and foreign creditors. They confer part of the risk on foreign creditors since their returns are cyclical. ${ }^{14}$ This feature makes them more attractive for borrowers.

The main difference between FDI and PEI is that the first is considered as a long-run commitment, whereas the latter may be purely part of the optimal portfolio allocation of a foreign investor. FDI investors show interest in the economic activities of the firm and assume managerial rights.

\footnotetext{
${ }^{14}$ Returns are higher if the project is successful and returns are depressed if the project turns out to be an economic failure.
} 
Thanks to the transfer of technological know-how and managerial practices FDI offers greater positive externalities than PEI. PEI, in turn, is more liquid than FDI since it may be sold at the stock market at any time. FDI is more costly to reverse because of high transaction costs or a low recovery value.

In comparison to PEI and debt investment, FDI is less affected by asymmetric information because investors participate in the management of the project and because they have access to insider information. This might be a reason why PEI projects are managed less efficiently than FDI projects (see Goldstein and Razin, 2006).

This information asymmetry between domestic and foreign investors might result in a lemons type problem: Since foreign investors observe average firm productivity (domestic investors observe firm-specific productivities), high productivity firms will be purchased by domestic agents and only shares of low-productivity firms are offered to foreign investors. Knowing this, foreign investors equity purchases are below an efficient level. Gordon and Bovenberg (1996) and Razin et al. (1998) propose that a subsidy to foreign equity investment may correct this market failure. Central banks' international reserves are an indirect way of subsidizing foreign investors and may alleviate this market failure.

Figure 2 shows that the ratio of PEI to FDI is relatively low in emerging markets compared to industrialized countries. This might indicate that the level of PEI is below its efficient level in emerging markets. As shown in our theoretical and empirical analysis, reserve hoardings might contribute to an increase of PEI relative to FDI.

The benefits from an increase in cross-border equity holdings might be substantial (see Rogoff, 1999): Equity trades allow small countries whose production depends on a small number of goods to diversify their income risk. Moreover, equity facilitates investment in riskier but high-yielding projects. Additional benefits of international equity flows might be indirect: Portfolio equity flows may be conducive to the development of domestic stock 
markets (Lane and Milesi-Ferretti, 2000). Stock market development, in turn, promotes the development of the domestic banking system (Demirgüc-Kunt and Levine, 1996).

\section{Concluding remarks}

In sum, we find that a higher level of international reserves is associated with more PEI relative to FDI inflows. Some push and pull factors, including stock market capitalization, institutional quality, the world long-term interest rate, as well as trade openness of an emerging market, are also found to significantly affect the composition of equity investment. A financial crisis in an emerging market reduces the ratio of short-term equity investment, PEI, relative to the long-term commitment, FDI.

Interestingly, we do not find any significant influence of capital controls on the ratio of PEI to FDI. This might be attributed to the fact that the effectiveness of capital controls is not adequately accounted for by existing measures of de jure capital mobility.

Our results may also imply that central banks’ reserves offer collateral benefits: By attracting PEI, they contribute to the development of domestic financial markets and facilitate domestic firms' access to external financial resources. If PEI replaces portfolio debt financing, it allows investors to share risk with their creditors (Faria et al, 2007). Thereby, reserves may help to shift the composition of foreign equity capital in emerging markets to levels observed in industrial countries (see Figure 2).

These findings, however, also reveal a possible dilemma: Central banks’ intention to reduce crisis vulnerability by the accumulation of a large stock of reserves might partly be offset by the endogenous response of market participants: Reserves tilt the composition of flows towards PEI, which can easily be reversed.

These concerns are confirmed by Eichler and Maltritz (2011a, 2011b) who find that the probability of a stock market crisis increases when stock holdings by foreigners increase 
relative to international reserves. A stock market crisis, in turn, is associated with a currency crisis.

The behavior of foreign stock market investors may destabilize the foreign exchange market: When they sell their stocks and transfer the funds in their home country, the proceeds, which are denoted in the emerging-market currency, are converted into US dollars. Hence, the implicit reserve demand of foreign investors grows one by one with the value of their stocks. Central banks might prepare for this implicit reserve demand by accumulating reserves when capital flows in. However, even if they accommodate all capital inflows by an equal increase in the domestic money supply, reserves do not cover the implicit reserve demand because of a return discrepancy: While the implicit reserve demand is linked to the stock market development, reserves are invested in low-yielding government bonds. This makes emerging markets with booming stock markets especially vulnerable to currency crises. 


\section{Appendix A: Capital inflows - growth versus crises}

In order to gauge the economic impact of different types of capital flows this appendix provides a nonexhaustive literature review of the effects of capital inflows on economic growth and crisis incidence.

\section{Growth}

The composition of capital flows matters because they may affect economic growth. Borensztein et al. (1998) find a positive growth effect of FDI. First, FDI gives developing countries access to advanced technologies. Second, FDI positively affects domestic investment (crowding-in effect).

Bekaert and Harvey (2000) demonstrate that private equity flows from the US positively affect emerging markets' growth. Durham (2003), in contrast, reports an insignificant effect of the sum of FDI and PEI on growth.

Aizenman ans Sushko (2011a) investigate the growth effects of different types of capital flows: While FDI inflows are found to enhance growth, overall PEI inflows are negatively associated with growth. In a restricted sample of financially-constrained firms, however, PEI inflows increase growth.

In a related paper (Aizenman and Sushko, 2011b) the authors investigate the effect of capital inflow types on the probability of economic takeoffs, defined as a five year period of sustained growth. Both short-term debt and portfolio equity flows reduce the probability of a takeoff.

\section{$\underline{\text { Crises }}$}

Joyce (2011) finds that foreign debt liabilities increase the probability of a banking crisis, whereas portfolio flows - FDI and PEI - make a crisis less likely to happen. Levchenko and Mauro (2007) report that both FDI and PEI play no role around sudden stop episodes.

Tong and Wei (2010) study whether the credit crunch during the financial crisis of 2008-10 depends on the pre-crisis composition of capital flows. The credit crunch is found to be more severe for firms that relied more on non-FDI capital flows. The decline of stock prices was stronger for firms that were more dependent on external sources of financing. 


\section{Appendix B: Variable Definitions}

PEI

FDI

GDP

Real GDP growth

Trade Openness

Natural resources

Stock market capitalization

Institutional quality

International reserves

World short-term interest rate

World long-term interest rate

Capital controls

Crisis

Mexican crisis 1994

East Asian crisis 1997

Trend
Stock data of portfolio equity investment in million USD.

[Source: Lane and Milesi-Ferretti (2007) EWN II data set]

FDI stock data in million USD. [Source: Lane and Milesi-Ferretti (2007) EWN II data set]

The host country's GDP in current USD. [Source: World Bank, World Development Indicators]

The host country's real GDP growth rate. [Source: World Bank, World Development Indicators]

The host country's trade openness, calculated as total trade scaled by the GDP. [Source: World Bank, World Development Indicators]

The host country's output of natural resources, calculated as total output of oil and mineral scaled by GNI. [Source: World Bank, World Development Indicators]

The host country's stock market capitalization over GDP. [Source: World Bank, World Development Indicators]

Index of institutional quality, measured as the sum of the index of corruption and the index of law and order. [Source:ICRG]

International reserves minus gold over GDP. [Source: World Bank, World Development Indicators]

World short-term interest rate, measured by the US 3-month Tbill rate. [Source: the US Treasury Department]

World long-term interest rate, measured by the US 10-year Treasury Bond yield. [Source: the US Treasury Department]

Measure for capital controls, using Chinn-Ito index (Chinn and Ito, 2006)

Dummy variable for currency crises, calculated according to Kaminsky and Reinhart (1999).

Dummy variable for the 1994 Mexican crisis, $\mathrm{I}(\mathrm{t}>94)=1$, otherwise, 0 .

Dummy variable for the 1997 Asian financial crisis, $\mathrm{I}(\mathrm{t}>97)=1$, otherwise, 0 .

A time trending variable. 


\section{References}

Acharya, Viral, Hyun Song Shin and Tanju Yorulmazer (2011), “Fire-sale FDI”, Princeton University, Working Paper.

Aguiar, Mark and Gita Gopinath (2005), "Fire-sale foreign direct investment and liquidity crises", Review of Economics and Statistics 87(3): 439-452.

Aizenman, Joshua and Daniel Riera-Crichton (2008), "Real exchange rate and international reserves in an era of growing financial and trade integration”, Review of Economics and Statistics 90: 812-815.

Aizenman, Joshua and Nancy Marion (2004), "International reserve holdings with sovereign risk and costly tax collection”, Economic Journal 114: 569-591.

Aizenman, Joshua and Vladyslav Sushko (2011a), “Capital flow types, external financing needs, and industrial growth: 99 countries, 1991-2007”, NBER Working Paper 17228.

Aizenman, Joshua and Vladyslav Sushko (2011b), "Capital flows: catalyst or hindrance to economic takeoffs?”, NBER Working Paper 17258.

Alfaro, Laura and Fabio Kanczuk (2009), “Debt maturity: Is long-term debt optimal?”, Review of International Economics 17, No. 5: 890-905.

Anderson, Theodore W. and Cheng Hsiao (1981), "Estimation of dynamic models with error components”, Journal of American Statistical Association, 76, 598-606.

Arellano, Manuel and Stephen Bond (1991), "Some tests of specification for panel data: Monte Carlo evidence and an application to employment equations”, Review of Economic Studies 58: 27797.

Arellano, Manuel and Olympia Bover (1995), "Another look at the instrumental variables estimation of error components models,” Journal of Econometrics 68: 29 -51.

Bekaert, Geert and Campbell R. Harvey (2000), “Foreign speculators and emerging equity markets”, Journal of Finance 55: 565-613.

Blundell, Richard and Stephen Bond (1998), "Initial conditions and moment restrictions in dynamic panel data models”, Journal of Econometrics Vol. 87, No.1: 115-143.

Borensztein, Eduardo, José de Gregorio and Jong-Wha Lee (1998), "How does foreign direct investment affect economic growth?”, Journal of International Economics 45: 115-135.

Burnside, Craig, Martin Eichenbaum and Sergio Rebelo (2001), "Hedging and financial fragility in fixed exchange rate regimes”, European Economic Review, Volume 45(7): 1151-1193.

Caballero Ricardo J. and Arvind Krishnamurthy (2001), "International and domestic collateral constraints in a model of emerging market crises", Journal of Monetary Economics 48(3): 513-548.

Calvo, Guillermo, Leonardo Leiderman and Carmen Reinhart (1993), "Capital inflows and the real exchange rate appreciation in Latin America: the role of external factors", IMF Staff Papers, Vol. 40(1): 108-151.

Chow, Gregory C. (1967), “Technological change and the demand for computers”, American Economic Review, 57, 1117 - 1130.

Chinn, Menzie D. and Hiro Ito (2006), "What matters for financial development? Capital controls, institutions, and interactions”, Journal of Development Economics, Vol. 81(1): 163-192.

Chuhan, Punam, Stijn Claessens and Nlandu Mamingi (1998), "Equity and bond flows to Latin America and Asia: the role of global and country factors", Journal of Development Economics, Vol. 55 (April): 439-63. 
De Gregorio, José and Jong-Wha Lee (2004), "Growth and adjustment in East Asia and Latin America", Economía Vol. 5, No.1: 69-115.

Demirgüç-Kunt, Asli and Ross Levine (1996), "Stock market development and financial intermediaries: stylized facts”, World Bank Economic Review 10(2): 291-321.

Durham, J. Benson (2003), "Foreign portfolio investment, foreign bank lending, and economic growth”, Board of Governors of the Federal Reserve System, International Finance Discussion Papers No. 757.

Eichler, Stefan and Dominik Maltritz (2011a), "Stock market-induced currency crises - a new type of twins”, Review of Development Economics, 15(2): 223-236.

Eichler, Stefan and Dominik Maltritz (2011b), "Currency crises and the stock market: empirical evidence for another type of twin crisis", Applied Economics, forthcoming.

Fama, Eugene F. (1981), "Stock returns, real activity, inflation, and money”, American Economic Review, Vol. 71(4): 545-565.

Faria, André, Philip Lane, Paolo Mauro, and Gian Maria Milesi-Ferretti (2007), “The shifting composition of external liabilities”, Journal of the European Economic Association, 5, 480490.

Fernandez-Arias, Eduardo (1996), “The new wave of private capital inflows: push or pull?” Journal of Development Economics, Vol. 48: 382-418.

Fernández-Arias, Eduardo and Ricardo Hausmann (2001), "Is foreign direct investment a safer form of financing?”, Emerging Markets Review, Volume 2(1): 34-49.

Frankel, Jeffrey A. and George Saravelos (2010), “Are leading indicators of financial crises useful for assessing country vulnerability? Evidence from the 2009-09 global crisis", NBER Working Paper 16047.

Goldstein, Itay and Assaf Razin (2006), “An information-based tradeoff between foreign direct investment and foreign portfolio investment”, Journal of International Economics 70: 271295.

Goldstein, Itay, Assaf Razin and Hui Tong (2008), “Liquidity, institutional quality and the composition of international equity flows”, NBER Working Paper 15727.

Gordon, Roger H. and A. Lans Bovenberg (1996), "Why is capital so immobile internationally? Possible explanations and implications for capital income taxation”, American Economic Review, Vol. 86(5): 1057-75.

Granger, Clive J., Bwo-Nung Huang and Chin-Wei Yang (2000),“A bivariate causality between stock prices and exchange rates: evidence from recent Asian flu”, Quarterly Review of Economics and Finance 40:337-54.

Hale, Galina (2007), “Bonds or loans? The effect of macroeconomic fundamentals”, The Economic Journal 117: 196-215.

Hansen, Lars Peter (1982), "Large sample properties of Generalized Method of Moments Estimators”, Econometrica 50, 3, 1029 -54.

Joyce, Joseph P. (2011), "Financial globalization and banking crises in emerging markets”, Open Economies Review, forthcoming.

Kaminsky, Graciela L. and Carmen M. Reinhart (1999), "The twin crises: the causes of banking and balance-of-payments problems”, American Economic Review, Vol. 89(3): 473-500.

Kirabaeva, Koralai and Assaf Razin (2010), “Composition of capital inflows: a survey”, NBER Working Paper 16492.

Krugman, Paul (2000), “Fire-Sale FDI,” in: Paul Krugman, Capital flows and the emerging economies: theory, evidence and controversies, Chicago, pp. 43-60. 
Lane, Philip R. and Gian Maria Milesi-Ferretti (2000), "External capital structure: theory and evidence”, IMF Working Paper 00/152.

Lane Philip R. and Gian Maria Milesi-Ferretti (2007), "The external wealth of nations mark II: Revised and extended estimates of foreign assets and liabilities, 1970-2004", Journal of International Economics 73, November: 223-250.

Lane, Philip R. and Gian Maria Milesi-Ferretti (2008), “The drivers of financial globalization”, American Economic Review: Papers \& Proceedings 98(2): 327-332.

Levchenko, Andrei A. and Paolo Mauro (2007), "Do some forms of financial flows help protect against “sudden stops”?”, The World Bank Economic Review 21(3): 389-411.

Li, Jie and Ramkishen S. Rajan (2009), "Can high reserves offset weak fundamentals? A simple model of precautionary demand for reserves”, Economia Internazionale (International Economics), LIX: 317-28.

Martínez, Lorenza and Alejandro Werner (2002), “The exchange rate regime and the currency composition of corporate debt: the Mexican experience”, Journal of Development Economics, Volume 69(2): 315-334.

Magud, Nicolas, Carmen Reinhart and Kenneth Rogoff (2011), "Capital controls: myth and reality - a portfolio balance approach,” NBER Working Paper 16805.

Malliaropulos, Dimitrios (1998), "International stock return differentials and real exchange rate changes”, Journal of International Money and Finance, Volume 17(3): 493-511.

McKinsey Global Institute (2011), “Mapping global capital market 2011”, McKinsey and Company.

Milesi-Ferretti, Gian-Maria and Cédric Tille (2011), “The great retrenchment: international capital flows during the global financial crisis”, Economic Policy 26(66): 289-346.

Montiel, Peter, and Carmen M. Reinhart (1999), "Do capital controls and macroeconomic policies influence the volume and composition of capital flows? Evidence from the 1990s”, Journal of International Money and Finance, Vol. 18: 619-35.

Obstfeld, Maurice, Jay C. Shambaugh and Alan M. Taylor (2009), "Financials instability, reserves, and central bank swap lines in the panic of 2008", American Economic Review: Papers and Proceedings, Vol. 99(2): 480-486.

Ostry, Jonathan D., Atish R. Ghosh, Karl Habermeier, Marcos Chamon, Mahvash S. Qureshi and Dennis B. S. Reinhardt (2010), "Capital inflows: the role of controls”, IMF Staff Position Note SPN/10/04.

Portes, Richard, and Hélène Rey (2005), “The determinants of cross-border equity flows”, Journal of International Economics, Vol. 65, Issue 2: 269-296.

Razin, Assaf, Efraim Sadka and Chi-Wa Yuen (1998), “A pecking order of capital inflows and international tax principles”, Journal of International Economics 44: 45-68.

Reinhart, Carmen M. and Kenneth S. Rogoff (2011), "From financial crash to debt crisis”, American Economic Review 101: 1676-1706.

Rogoff, Kenneth (1999), “International institutions for reducing global financial instability”, Journal of Economic Perspectives, Vol. 13, No. 4: 21-42.

Tirole, Jean (2003), “Inefficient foreign borrowing: a dual- and common-agency perspective”, American Economic Review, Vol. 93(5): 1678-1702.

Tong, Hui and Shang-Jin Wei (2011), "The composition matters: capital inflows and liquidity crunch during a global economic crisis”, Review of Financial Studies 24(6): 2023-2052.

Wei, Shang-Jin and Yi Wu (2002), "Negative alchemy? Corruption, composition of capital flows, and currency crises”, in: Sebastian Edwards and Jeffrey A. Frankel (eds.), Preventing currency 
crises in emerging markets, NBER Books, National Bureau of Economic Research, Inc, pages 461-506.

Wheeler, David And Ashoka Mody (1992), "International investment location decisions: the case of US firms”, Journal of International Economics 33(1-2): 57-76.

Windmeijer, Frank (2005), “A finite sample correction for the variance of linear efficient two-step GMM estimators”, Journal of Econometrics 126: 25-51. 
Figure 1: International reserves and the composition of equity capital inflows
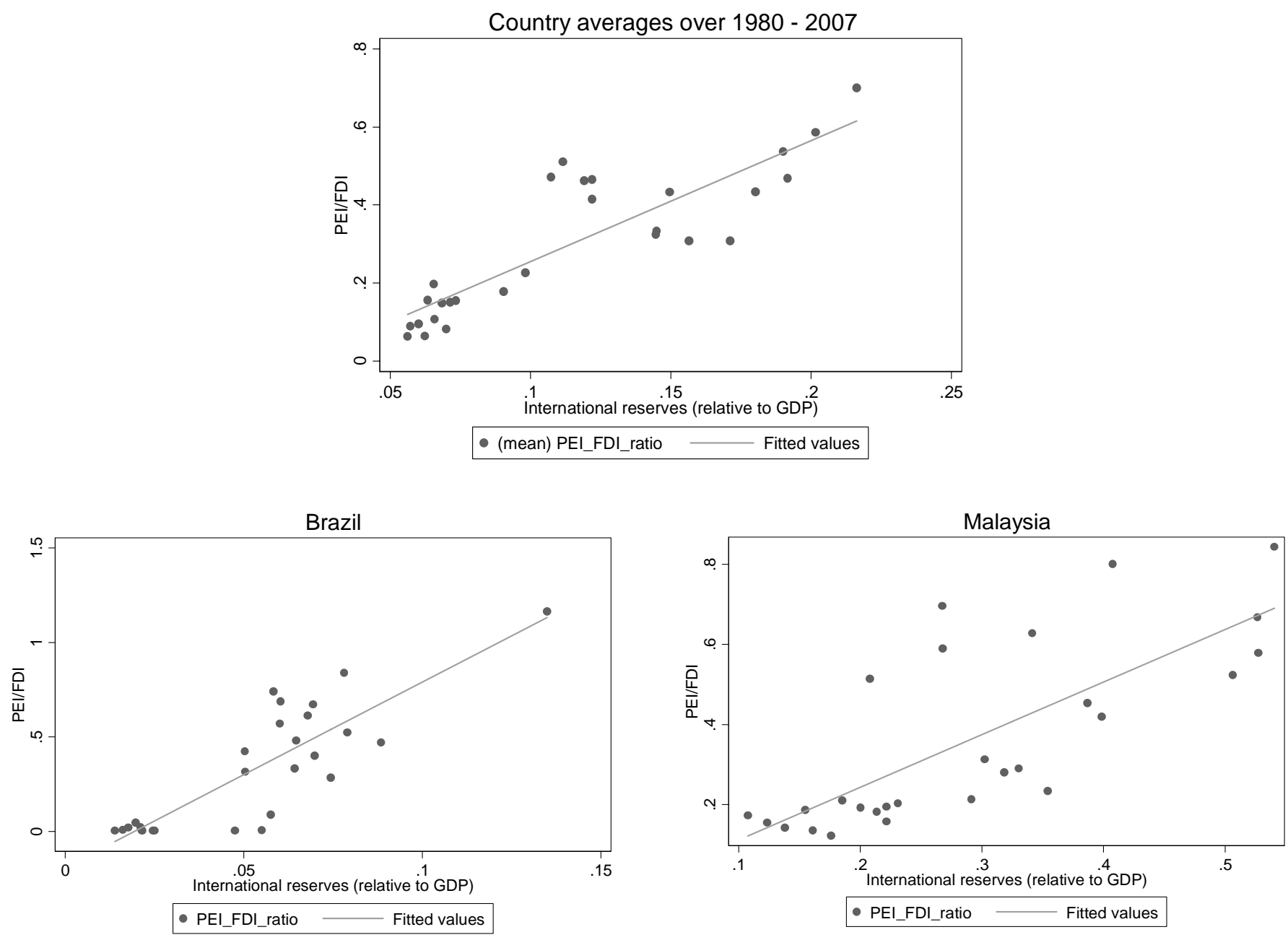

Figure 2: PEI relative to FDI in industrial countries and emerging markets

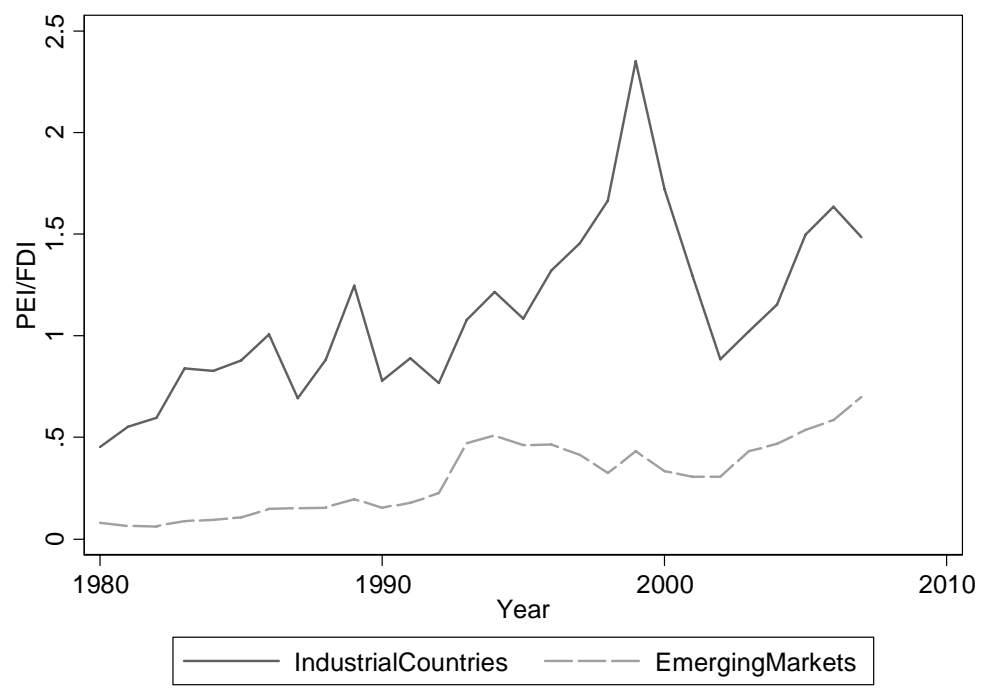


Table 1: Static Panel Regression regarding the choice of PEI or FDI

\begin{tabular}{|c|c|c|c|}
\hline & A & B & C \\
\hline Stock market capitalization & $\begin{array}{r}0.387 * * * \\
(0.07)\end{array}$ & $\begin{array}{r}0.409 * * * \\
(0.08)\end{array}$ & $\begin{array}{r}0.404^{* * *} \\
(0.09)\end{array}$ \\
\hline Institutional quality & $\begin{array}{r}0.032^{* * * *} \\
(0.01)\end{array}$ & $\begin{array}{r}0.028^{* *} \\
(0.01)\end{array}$ & $\begin{array}{r}0.028^{* *} \\
(0.01)\end{array}$ \\
\hline International reserves & $\begin{array}{r}0.767 * * \\
(0.32)\end{array}$ & $\begin{array}{r}0.733^{* *} \\
(0.35)\end{array}$ & $\begin{array}{r}0.722^{* *} \\
(0.35)\end{array}$ \\
\hline World short-term interest rate & $\begin{array}{c}0.002 \\
(0.01)\end{array}$ & $\begin{array}{l}0.018 \\
(0.01)\end{array}$ & $\begin{array}{c}0.019 \\
(0.01)\end{array}$ \\
\hline GDP & $\begin{array}{l}0.051 \\
(0.05)\end{array}$ & $\begin{array}{c}0.049 \\
(0.05)\end{array}$ & $\begin{array}{r}0.050 \\
(0.05)\end{array}$ \\
\hline Natural resources & $\begin{array}{l}-0.006 \\
(0.01)\end{array}$ & $\begin{array}{l}-0.002 \\
(0.01)\end{array}$ & $\begin{array}{l}-0.004 \\
(0.01)\end{array}$ \\
\hline Trade openness & $\begin{array}{r}-0.380^{* *} \\
(0.16)\end{array}$ & $\begin{array}{r}-0.347 * * \\
(0.16)\end{array}$ & $\begin{array}{r}-0.356 * * \\
(0.17)\end{array}$ \\
\hline World long-term interest rate & $\begin{array}{l}-0.011 \\
(0.02)\end{array}$ & $\begin{array}{r}-0.042 * * \\
(0.02)\end{array}$ & $\begin{array}{r}-0.040^{* *} \\
(0.02)\end{array}$ \\
\hline Real GDP growth & $\begin{array}{c}0.003 \\
(0.00)\end{array}$ & $\begin{array}{l}0.002 \\
(0.00)\end{array}$ & $\begin{array}{l}0.002 \\
(0.00)\end{array}$ \\
\hline Crisis & & $\begin{array}{l}-0.038 \\
(0.03)\end{array}$ & $\begin{array}{r}-0.039 \\
(0.03)\end{array}$ \\
\hline Mexican crisis 1994 & & $\begin{array}{r}-0.109 * * \\
(0.05)\end{array}$ & $\begin{array}{r}-0.103^{*} \\
(0.05)\end{array}$ \\
\hline East Asian crisis 1997 & & $\begin{array}{r}-0.134^{* * *} \\
(0.05)\end{array}$ & $\begin{array}{r}-0.138^{* * *} \\
(0.05)\end{array}$ \\
\hline Capital controls & & & $\begin{array}{r}-0.011 \\
(0.02)\end{array}$ \\
\hline Trend & $\begin{array}{r}0.009 \\
(0.01)\end{array}$ & $\begin{array}{r}0.024 * * \\
(0.01)\end{array}$ & $\begin{array}{r}0.025^{* *} \\
(0.01)\end{array}$ \\
\hline Constant & $\begin{array}{r}-1.247 * * * \\
(0.36)\end{array}$ & $\begin{array}{r}-1.218^{* * *} \\
(0.36)\end{array}$ & $\begin{array}{r}-1.252 * * * \\
(0.37)\end{array}$ \\
\hline R-Squared & 0.18 & 0.20 & 0.20 \\
\hline Obs. & 442 & 384 & 380 \\
\hline
\end{tabular}

Note: The table reports the results of estimating equation (3) with static panel data, Quasi-GLS regression. Robust errors are in parentheses underneath coefficient estimates. “***, **, *” indicate 1\%, 5\%, and 10\% level of significance, respectively. 
Table 2: Dynamic panel regression (fixed effects OLS) for the choice of PEI or FDI

\begin{tabular}{|c|c|c|c|}
\hline & A & B & $\mathrm{C}$ \\
\hline PEI/FDI(-1) & $\begin{array}{r}0.737 * * * \\
(0.06)\end{array}$ & $\begin{array}{r}0.706^{* * * *} \\
(0.05)\end{array}$ & $\begin{array}{r}0.698^{* * *} \\
(0.05)\end{array}$ \\
\hline Stock market capitalization & $\begin{array}{r}0.111^{* * * *} \\
(0.04)\end{array}$ & $\begin{array}{r}0.142 * * * \\
(0.05)\end{array}$ & $\begin{array}{r}0.136 * * * \\
(0.05)\end{array}$ \\
\hline Institutional quality & $\begin{array}{l}0.008 \\
(0.01)\end{array}$ & $\begin{array}{c}0.011 \\
(0.01)\end{array}$ & $\begin{array}{l}0.012 \\
(0.01)\end{array}$ \\
\hline International reserves & $\begin{array}{r}0.430^{*} \\
(0.24)\end{array}$ & $\begin{array}{c}0.250 \\
(0.23)\end{array}$ & $\begin{array}{l}0.177 \\
(0.23)\end{array}$ \\
\hline World short-term interest rate & $\begin{array}{r}-0.020^{* *} \\
(0.01)\end{array}$ & $\begin{array}{r}-0.015^{* *} \\
(0.01)\end{array}$ & $\begin{array}{r}-0.017^{* *} \\
(0.01)\end{array}$ \\
\hline GDP & $\begin{array}{r}0.033 \\
(0.04)\end{array}$ & $\begin{array}{l}0.004 \\
(0.06)\end{array}$ & $\begin{array}{l}0.013 \\
(0.05)\end{array}$ \\
\hline Natural resources & $\begin{array}{l}0.003 \\
(0.00)\end{array}$ & $\begin{array}{r}0.005 \\
(0.01)\end{array}$ & $\begin{array}{l}0.002 \\
(0.01)\end{array}$ \\
\hline Trade openness & $\begin{array}{r}-0.191^{* *} \\
(0.08)\end{array}$ & $\begin{array}{r}-0.206^{* *} \\
(0.08)\end{array}$ & $\begin{array}{r}-0.225^{* *} \\
(0.11)\end{array}$ \\
\hline World long-term interest rate & $\begin{array}{r}-0.007 \\
(0.01)\end{array}$ & $\begin{array}{r}-0.014 \\
(0.01)\end{array}$ & $\begin{array}{r}-0.008 \\
(0.01)\end{array}$ \\
\hline Real GDP growth & $\begin{array}{c}0.004 \\
(0.00)\end{array}$ & $\begin{array}{r}0.003 \\
(0.00)\end{array}$ & $\begin{array}{l}0.003 \\
(0.00)\end{array}$ \\
\hline Crisis & & $\begin{array}{r}-0.075^{* *} \\
(0.03)\end{array}$ & $\begin{array}{r}-0.081^{* *} \\
(0.03)\end{array}$ \\
\hline Mexican crisis 1994 & & $\begin{array}{l}-0.069 \\
(0.06)\end{array}$ & $\begin{array}{r}-0.071 \\
(0.06)\end{array}$ \\
\hline East Asian crisis 1997 & & $\begin{array}{l}-0.035 \\
(0.04)\end{array}$ & $\begin{array}{r}-0.032 \\
(0.04)\end{array}$ \\
\hline Capital controls & & & $\begin{array}{r}-0.019 \\
(0.01)\end{array}$ \\
\hline Trend & $\begin{array}{r}-0.006 \\
(0.01)\end{array}$ & $\begin{array}{c}0.002 \\
(0.01)\end{array}$ & $\begin{array}{l}0.005 \\
(0.01)\end{array}$ \\
\hline Constant & $\begin{array}{r}-0.560 \\
(0.96)\end{array}$ & $\begin{array}{l}0.143 \\
(1.34)\end{array}$ & $\begin{array}{r}-0.131 \\
(1.24)\end{array}$ \\
\hline R-Squared & 0.69 & 0.67 & 0.67 \\
\hline Obs. & 464 & 405 & 402 \\
\hline
\end{tabular}

Note: The table reports the results of estimating equation (4) with the dynamic panel data, Quasi-GLS regression. Robust errors are in parentheses underneath coefficient estimates. “***, **, *” indicate $1 \%$, $5 \%$, and $10 \%$ level of significance, respectively. 
Table 3: Dynamic Panel Regression (System-GMM) for the choice of PEI or FDI

\begin{tabular}{|c|c|c|c|}
\hline & A & B & C \\
\hline \multirow[t]{2}{*}{ PEI/FDI(-1) } & $0.847^{* * *}$ & $0.835^{* * *}$ & $0.834^{* * *}$ \\
\hline & $(0.08)$ & $(0.07)$ & $(0.07)$ \\
\hline \multirow{2}{*}{ Stock market capitalization } & $0.213^{* * *}$ & $0.204^{* * *}$ & $0.182 * * *$ \\
\hline & $(0.06)$ & $(0.07)$ & $(0.05)$ \\
\hline \multirow[t]{2}{*}{ Institutional quality } & $-0.024^{* *}$ & -0.005 & -0.001 \\
\hline & $(0.01)$ & $(0.02)$ & $(0.02)$ \\
\hline \multirow[t]{2}{*}{ International reserves } & $1.757^{* *}$ & $1.335^{*}$ & $1.111^{*}$ \\
\hline & $(0.83)$ & $(0.68)$ & $(0.57)$ \\
\hline \multirow[t]{2}{*}{ World short-term interest rate } & $-0.019 * *$ & -0.012 & -0.008 \\
\hline & $(0.01)$ & $(0.01)$ & $(0.01)$ \\
\hline \multirow[t]{2}{*}{ GDP } & 0.039 & 0.022 & 0.020 \\
\hline & $(0.04)$ & $(0.04)$ & $(0.04)$ \\
\hline \multirow[t]{2}{*}{ Natural resources } & -0.005 & -0.004 & -0.002 \\
\hline & $(0.01)$ & $(0.01)$ & $(0.01)$ \\
\hline \multirow[t]{2}{*}{ Trade openness } & $-0.368 * *$ & $-0.251^{*}$ & $-0.270 * *$ \\
\hline & (0.14) & $(0.13)$ & $(0.13)$ \\
\hline \multirow[t]{2}{*}{ World long-term interest rate } & -0.004 & -0.012 & -0.017 \\
\hline & $(0.01)$ & $(0.01)$ & $(0.02)$ \\
\hline \multirow{2}{*}{ Real GDP growth } & 0.006 & 0.003 & 0.001 \\
\hline & $(0.01)$ & $(0.01)$ & $(0.01)$ \\
\hline \multirow[t]{2}{*}{ Crisis } & & $-0.127^{* *}$ & $-0.145^{* *}$ \\
\hline & & $(0.06)$ & $(0.06)$ \\
\hline \multirow[t]{2}{*}{ Mexican crisis 1994} & & -0.107 & -0.107 \\
\hline & & $(0.07)$ & $(0.07)$ \\
\hline \multirow[t]{2}{*}{ East Asian crisis 1997} & & 0.027 & 0.021 \\
\hline & & $(0.06)$ & $(0.06)$ \\
\hline \multirow[t]{2}{*}{ Capital controls } & & & 0.041 \\
\hline & & & $(0.03)$ \\
\hline \multirow[t]{2}{*}{ Trend } & $-0.015 *$ & -0.010 & -0.011 \\
\hline & $(0.01)$ & $(0.01)$ & $(0.01)$ \\
\hline \multirow[t]{2}{*}{ Constant } & $29.884 *$ & 20.011 & 21.343 \\
\hline & (16.87) & (18.54) & (19.46) \\
\hline Hansen & 8.02 & 5.17 & 4.81 \\
\hline $\mathrm{AR}(1)$ & $-2.63 * * *$ & $-2.42 * *$ & $-2.41 * *$ \\
\hline $\operatorname{AR}(2)$ & 0.88 & 0.98 & 1.02 \\
\hline Instruments & 94 & 86 & 86 \\
\hline Obs. & 464 & 405 & 402 \\
\hline
\end{tabular}

Note: The table reports the results of estimating equation (4) with the dynamic panel data, System-GMM regression. Robust errors are in parentheses underneath coefficient estimates. “***, **, *” indicate 1\%, $5 \%$, and $10 \%$ level of significance, respectively. 